\title{
Effects of Tillage Practices on Soil Properties under Maize Cultivation on Oxic Paleustalf in South Western Nigeria
}

\author{
Bola A. Senjobi ${ }^{*}$, Olufunmilayo T. Ande ${ }^{2}$, A. E. Okulaja ${ }^{3}$ \\ ${ }^{1}$ Federal University of Agriculture, Abeokuta, Nigeria; ${ }^{2}$ Institute of Agric Research and Training, Obafemi Awolowo University, \\ Apata, Ibadan; ${ }^{3}$ Department of Crop Production, Olabisi Onabanjo University, Ago-Iwoye, Nigeria. \\ Email: *bolasenjobi@gmail.com, ’senjobiba@funaab.org.ng, "bolasenjobi@yahoo.com, funmiande@yahoo.com
}

Received September $12^{\text {th }}, 2012$; revised May $18^{\text {th }}, 2013$; accepted May $27^{\text {th }}, 2013$

Copyright @ 2013 Bola A. Senjobi et al. This is an open access article distributed under the Creative Commons Attribution License, which permits unrestricted use, distribution, and reproduction in any medium, provided the original work is properly cited.

\begin{abstract}
A study was conducted to determine the effect of tillage practices on soil properties under maize cultivation in savanna ecosystem of South Western Nigeria. The tillage systems evaluated were zero, convectional and traditional tillage systems. The results showed that there is a significant difference in soil parameters and crop morphologies at $\mathrm{p}<0.05$ among the tillage systems. The traditional tillage system resulted to the most favorable soil environment, for crop growth and best performance of crop followed by conventional and no-tillage system in the area are studied respectively. The significant difference in yields adduced to lower bulk density, higher water holding capacity and porosity which increased plant root proliferation and optimal utilization of soil nutrients under tilled methods. Hence tillage methods have the capability to increase production while no-tillage is better under long term production for sustainable land use.
\end{abstract}

Keywords: Tillage Practices; Soil Properties; Maize; Sustainable Production

\section{Introduction}

The ever-increasing population scenario of Nigeria, makes it a necessity for more land to be opened up and efficiently managed for increased food production. The Nigerian traditional tillage method involves the use of hoes to make mounds size of which depends on the crop to be grown on. This method is gradually being replaced by conventional method of plough and harrow. Considering the fragile nature of Nigeria savannah soils, this method has further impoverished the soils due to erosion, increased loss of soil moisture by evaporation and compaction. Tillage, according to [1], is a terminology that is applied to the creation of enabling environment for the germination and growth of crops. Technically according to [2], tillage refers to the mechanical stirring of soil to provide a suitable soil environment for growth of crops. Ashaye [3] affirmed that the productivity of any soil depends on the way and how it is managed through cultivation practices imposed on it. Appropriate tillage practices are those that avoid the degradation of soil properties but maintain crop yields as well as ecosystem stability [4], [5,6]. In recent years, the interest in conservation tillage

\footnotetext{
*Corresponding author.
}

systems has increased in response to the need to limit erosion and promote water conservation [7,8]. This has been considered to provide the best opportunity for halting degradation and for restoring and improving soil productivity [9]. Conservation tillage is being adopted by local farmers in order to protect the soils from adverse effects of climate. However, the effects of this method need to be examined further in savanna soils of Nigeria characterized with limited rainfall, high temperature and fragile soils prone to erosion.

The major stable crop grown widely in south western savanna is maize which cultivation and utilization have increased due to greater demands for consumption and for industrial purposes. Hence more land is being opened up yearly to sustain increase demands. An understanding of the climate and soil environment is necessary in order to select appropriate management practices such as tillage practices, fertilization, irrigation etc., as well as modification of the soil nutrients to optimize maize yield. This has necessitated the use of modern implements for tillage practices to facilitate farming operations. However, poor choice of implements and soil management practices, inappropriate tillage systems, seed bed types have often been identified as major constraints to cereal crop 
production in the savannah agro-ecological zones of South-Western, Nigeria [6]. Lal [6], therefore advocated that in tropical countries, soil tillage practices that have significant effects compared to zero tillage should be encouraged since mechanized tillage appeared to be indispensable in large scale farming. This is necessary, since a granular structure does not only encourage rapid infiltration and good retention of rainfall but also provides adequate moisture, air exchange capacity within the soil and minimizes resistance to root penetration.

This study was carried out to examine the influence of tillage practices on properties of soils under a maize cultivation and to determine the effective and appropriate tillage practice(s) for sustainable maize production.

\section{Materials and Methods}

\subsection{Field Work}

Composite surface samples $(0-15 \mathrm{~cm})$ and sub-surface samples $(15-30 \mathrm{~cm})$ were taken at the lower slope of the toposequence selected for the research. In addition to the above, a representative profile pit was dug and samples were taken from it. These were later air-dried, crushed and sieved before taken to the laboratory for physical and chemical analyses of the soils.

Three tillage operations were imposed on the soil. These were traditional, conventional and zero tillage operations. The experiments were laid out in a randomized complete block design with three replicates. Maize was used as test crop and morphological properties such as stem girth, number of internodes, number of cob/plant, fresh weight of cobs with bract. Fresh weight of grains cob, fresh weight of 10 grains and grain yield/ha were taken.

\subsection{Laboratory Analyses}

Soil analysis were carried out later to observe the variations in soil properties due to applied different tillage operations. The soil particle size analysis was done mechanically by using the hydrometer method of Bouyou$\cos$ [10] with sodium hexa-metaphosphate as the dis- persing agent. Soil $\mathrm{pH}$ was determined potentiometrically in both water and $0.01 \mathrm{M}$ Potassium Chloride solution (1.1). Exchangeable bases were extracted with neutral ammonium acetate solution; $\mathrm{Ca}$ and $\mathrm{Mg}$ were determined by atomic absorption spectrophotometer, and $\mathrm{K}$ and $\mathrm{Na}$ by flame photometer. Exchangeable acidity was determined by the KCL extraction method [11]. Total nitrogen was determined by the macro-kjeldah method [12]. Available Phosphorus was determined by the Bray and Kurtz [13], method and organic carbon by the method of Walkley and Black [14]. ECEC was determined as the sum of exchangeable bases and exchangeable acidity.

All the parameters collected were subjected to analysis of variance and the means were compared using Duncan Multiple Range Test.

\section{Results and Discussion}

Table 1 shows the result of the physical and chemical properties of the profile pit dug on the experimental site. The soil textures ranged from clay loam to sandy clay. The bulk density ranged from 1.24 to $1.59 \mathrm{~g} / \mathrm{cm}^{3}$. Gravel concentration and total porosity around the rooting zone were $28.7 \%$ to $66.8 \%$ and $40.0 \%$ to $53.3 \%$ respectively.

Hydraulic conductivity, permeability and water holding capacity (WHC) fluctuated with depth down the profile. This may probably be due to variation in soil texture down the profile pit. The organic carbon, $\mathrm{pH}$ and exchangeable bases with exception of potassium and sodium decreases with depth down the pit. The soil was classified as Oxic Paleustalf because of its Ustic moisture regime, percent CEC greater than $35 \%$ in the sub soil and Oxic diagnostic horizon.

Table 2 shows the soil properties of the studied site before tillage at $0-15 \mathrm{~cm}$ and $15-30 \mathrm{~cm}$ depths. It was observed that the bulk density and porosity decreased with depth while the $\mathrm{pH}$ varied between 4.82 and 4.85 . The organic carbon and exchangeable bases with the exception of phosphorus were low. The low nutrient status of the soil might be due to continuous cultivation without corresponding return of organic materials to the soil. The clay content range from $28.8 \%$ to $30.4 \%$ while

Table 1. Physical and chemical properties of the soil profile of studied site.

\begin{tabular}{|c|c|c|c|c|c|c|c|c|c|c|c|c|c|c|c|c|c|c|c|c|c|}
\hline 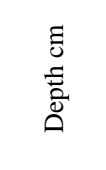 & 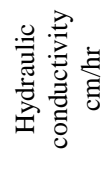 & 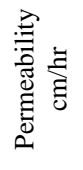 & 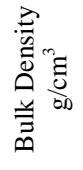 & $\begin{array}{l}00 \\
: \\
\frac{0}{5} \\
0 \\
0 \\
0\end{array}$ & 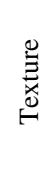 & $\begin{array}{l}d^{\circ} \\
\stackrel{u}{3} \\
3\end{array}$ & $\underset{0}{\stackrel{\vec{J}}{u}}$ & $\begin{array}{l}\stackrel{5}{5} \\
0^{\circ}\end{array}$ & 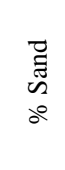 & 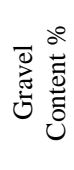 & $\begin{array}{l}z \\
\alpha^{0}\end{array}$ & $\begin{array}{l}\underset{N}{O} \\
\underset{I}{I} \\
\underset{D}{I}\end{array}$ & 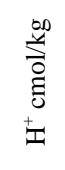 & $\begin{array}{l}\dot{0} \\
0 \\
0\end{array}$ & $\begin{array}{l}\frac{\infty}{00} \\
\frac{1}{2} \\
0\end{array}$ & 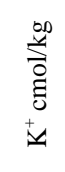 & 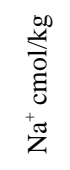 & 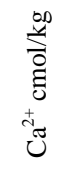 & 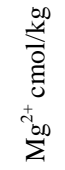 & 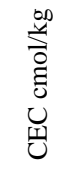 & $\begin{array}{l}\infty \\
\text { Dी } \\
d^{\circ}\end{array}$ \\
\hline $0-32$ & 370.8 & 258.6 & 1.12 & 53.5 & CL & 42.2 & 31.4 & 16.0 & 52.6 & 29.7 & 0.23 & 6.03 & 0.09 & 2.30 & 9.78 & 0.75 & 0.92 & 3.96 & 3.05 & 8.68 & 98.97 \\
\hline 32- 61 & 210.6 & 147.0 & 1.59 & 40.0 & SC & 27.9 & 49.4 & 18.0 & 32.6 & 66.8 & 0.04 & 5.01 & 0.08 & 0.55 & 2.13 & 0.72 & 0.87 & 3.34 & 2.55 & 7.48 & 98.94 \\
\hline $61-93$ & 390.0 & 271.8 & 1.58 & 40.4 & CL & 29.7 & 35.4 & 26.0 & 38.6 & 67.8 & 0.05 & 4.47 & 0.06 & 0.48 & 0.00 & 0.85 & 1.13 & 4.21 & 3.41 & 9.60 & 98.76 \\
\hline $93-150$ & 291.0 & 154.8 & 1.48 & 44.2 & SC & 36.3 & 41.4 & 20.0 & 38.6 & 19.6 & 0.00 & 3.48 & 0.03 & 0.01 & 0.00 & 0.62 & 0.85 & 4.07 & 3.28 & 8.82 & 99.66 \\
\hline
\end{tabular}


Table 2. Physical and chemical properties of the surface samples of the studied site before tillage.

\begin{tabular}{|c|c|c|c|c|c|c|c|c|c|c|c|c|c|c|c|c|c|}
\hline $\begin{array}{l}\text { Depth } \\
\text { cm }\end{array}$ & $\begin{array}{l}\text { Bulk } \\
\text { Density } \\
\mathrm{g} / \mathrm{cm}^{3}\end{array}$ & $\begin{array}{c}\text { Porosity } \\
\quad \%\end{array}$ & $\begin{array}{c}\% \\
\text { WHC }\end{array}$ & $\begin{array}{c}\% \\
\text { Clay }\end{array}$ & \% Silt & $\begin{array}{c}\% \\
\text { Sand }\end{array}$ & $\% \mathrm{~N}$ & $\begin{array}{c}\mathrm{pH} \\
\mathrm{H}_{2} \mathrm{O}\end{array}$ & $\begin{array}{c}\mathrm{H}^{+} \\
\mathrm{cmol} / \mathrm{kg}\end{array}$ & $\%$ O.C. & $\mathrm{P} \mu \mathrm{g} / \mathrm{g}$ & $\begin{array}{c}\mathrm{K}^{+} \\
\mathrm{cmol} / \mathrm{kg}\end{array}$ & $\begin{array}{c}\mathrm{Na}^{+} \\
\mathrm{cmol} / \mathrm{kg}\end{array}$ & $\begin{array}{c}\mathrm{Ca}^{2+} \\
\mathrm{cmol} / \mathrm{kg}\end{array}$ & $\begin{array}{c}\mathrm{Mg}^{2+} \\
\mathrm{cmol} / \mathrm{kg}\end{array}$ & $\begin{array}{c}\text { CCEC } \\
\mathrm{cmol} / \mathrm{kg}\end{array}$ & $\%$ BS \\
\hline $0-15$ & 1.14 & 50.5 & 42.5 & 28.8 & 19.4 & 57.8 & 0.08 & 4.82 & 0.11 & 0.83 & 2.98 & 0.73 & 0.94 & 2.12 & 1.89 & 5.68 & 98.10 \\
\hline $15-30$ & 1.12 & 48.2 & 44.6 & 30.4 & 16.7 & 52.9 & 0.09 & 4.85 & 0.09 & 0.74 & 2.74 & 0.70 & 0.80 & 2.33 & 2.04 & 5.87 & 98.49 \\
\hline
\end{tabular}

silt content ranged from $16.7 \%$ to $19.4 \%$ and the percentage sand varied from 52.9 to 57.8 .

Table 3 shows the physical and chemical properties of the surface soil of the studied site under zero tillage. The water holding capacity decreased down the soil depth while the porosity increased down the depth. The organic carbon and exchangeable base contents decreased down the depth, while the bulk density increased with depth.

Under conventional tillage system, the water holding capacity (WHC) and porosity decreased down the depth while the bulk density increased down the depth (Table 4). The organic carbon and exchangeable cations contents decreased more compare to zero tillage method.

The chemical properties of the surface soil under traditional tillage showed that the organic carbon content, exchangeable bases and water holding capacity values decreased with depth while the bulk density and porosity increased with depth (Table 5).

Generally, the values of the physical properties under the traditional and conventional tillage systems were significantly higher $(p<0.05)$ than those of the zero tillage (Figure 1). Figure 1 showed that tillage practices affected the bulk density, porosity and water holding capacity of the soil because of higher bulk density and lower infiltration rate of the soils under traditional and conventional tillage systems. Variation in the exchangeable bases across the different tillage methods, with consistent decreased in their values down the depth, was an indication that the planted crop, maize, (a surface feeder) obtained its nutrient from the topsoil. It further proved the nutrient depleting ability of the crop as shown in Figure 1. The water holding capacity of the tilled soil was higher than the untilled soil. This was because the bulk density of the tilled soil was lower than that of the untilled soil and the lower the bulk density, the higher the water holding capacity (Figure 1). The tillage of the soil therefore created a better soil physical environment for root growth and development. This was evident in the higher values of root volume in the tilled soil than in the untilled soils, with the conventional tillage greater than the traditional and zero tillage (Figure 2). There was no difference between the soil properties before tillage and under zero tillage (Tables 2 and 3). This may probably be due to the slashing of the bush regrowth at the site before the application of the herbicide (Round-up glyphosphate) for the effective weed control. It was ob- served from Figure 2 that most of the plant parameters were significantly different $(p<0.05)$ except fresh weight of 10 grains under the three tillage systems. It was observed that traditional tillage system performed better than conventional and zero tillage systems because of the highest stem height, leaf number, number of untilled soil. This was because the bulk density of the tilled soil was lower than that of the untilled soil and the lower the bulk density, the higher the water holding capacity (Figure 1). The tillage of the soil therefore created a better soil physical environment for root growth and development. This was evident in the higher values of root volume in the tilled soil than in the untilled soils, with the conventional tillage greater than the traditional and zero tillage (Figure 2). However, there was no difference between the soil properties before tillage and under zero tillage (Tables 2 and 3). This may probably be due to the slashing of the bush regrowth at the site before the application of the herbicide (Round-up glyphosphate) for the effective weed control. It was observed from Figure 2 that most of the plant parameters were significantly different ( $p<0.05$ ) except fresh weight of 10 grains under the three tillage systems. It was observed that traditional tillage system performed better than conventional and zero tillage systems because of the highest stem height, leaf number, and number of Cobs/plant, fresh weight of cob with bracts, and fresh weight of bract and fresh weight of 10 grains were obtained under the traditional tillage system. This may be due to the lower bulk density, high porosity and water drainage as shown in Tables 3-5. This is in accordance with the findings of [9], who noted that ridging system of field layout, in general improves soil drainage and crop performance compared with that planted on the no tilled soils.

The soils bulk density under traditional tillage system was lower than that of zero tillage which could have been as a result of pulverization of the soil which enhances plant root proliferation, leading to more of the soil being optimally used [4].

Tillage alters the soil environment by reducing the strength of the soil matrix and increasing the porosity thereby improving the permeability of the soil for the flow of both water and gas.

Osuji [15] findings on soils classified as Ferric Luvisol showed that nutrient accumulated under traditional tillage was relatively high after deeper ploughing; thereby 
Table 3. Physical and chemical properties of the surface samples of the studied site under zero tillage.

\begin{tabular}{|c|c|c|c|c|c|c|c|c|c|c|c|c|c|c|c|c|c|}
\hline $\begin{array}{l}\text { Depth } \\
\text { cm }\end{array}$ & $\begin{array}{l}\text { Bulk } \\
\text { Density } \\
\text { g/cm }{ }^{3}\end{array}$ & $\begin{array}{c}\text { Porosity } \\
\%\end{array}$ & $\begin{array}{c}\% \\
\text { WHC }\end{array}$ & $\begin{array}{c}\% \\
\text { Clay }\end{array}$ & $\begin{array}{c}\% \\
\text { Silt }\end{array}$ & $\begin{array}{c}\% \\
\text { Sand }\end{array}$ & $\begin{array}{l}\% \\
\mathrm{~N}\end{array}$ & $\begin{array}{c}\mathrm{pH} \\
\mathrm{H}_{2} \mathrm{O}\end{array}$ & $\begin{array}{c}\mathrm{H}^{+} \\
\mathrm{cmol} / \mathrm{kg}\end{array}$ & $\begin{array}{c}\% \\
\text { O.C. }\end{array}$ & $\begin{array}{c}\mathrm{P} \\
\mu \mathrm{g} / \mathrm{g}\end{array}$ & $\begin{array}{c}\mathrm{K}^{+} \\
\mathrm{cmol} / \mathrm{kg}\end{array}$ & $\begin{array}{c}\mathrm{Na}^{+} \\
\mathrm{cmol} / \mathrm{kg}\end{array}$ & $\begin{array}{c}\mathrm{Ca}^{2+} \\
\mathrm{cmol} / \mathrm{kg}\end{array}$ & $\begin{array}{c}\mathrm{Mg}^{2+} \\
\mathrm{cmol} / \mathrm{kg}\end{array}$ & $\begin{array}{c}\mathrm{CEC} \\
\mathrm{cmol} / \mathrm{kg}\end{array}$ & $\%$ BS \\
\hline $0-15$ & 1.26 & 48.6 & 37.2 & 25.4 & 14.0 & 60.6 & 0.04 & 5.64 & 0.08 & 1.31 & 1.57 & 0.63 & 0.72 & 2.42 & 2.23 & 6.00 & 98.68 \\
\hline $15-30$ & 1.31 & 53.7 & 35.1 & 31.4 & 16.0 & 52.6 & 0.03 & 4.58 & 0.08 & 1.02 & 1.38 & 0.58 & 0.62 & 2.33 & 2.03 & 5.58 & 98.59 \\
\hline
\end{tabular}

Table 4. Physical and chemical properties of the surface samples of the studied site under conventional tillage.

\begin{tabular}{|c|c|c|c|c|c|c|c|c|c|c|c|c|c|c|c|c|c|}
\hline $\begin{array}{l}\text { Depth } \\
\text { cm }\end{array}$ & $\begin{array}{c}\text { Bulk } \\
\text { Density } \\
\text { g/cm }\end{array}$ & $\begin{array}{c}\text { Porosity } \\
\%\end{array}$ & $\begin{array}{c}\% \\
\text { WHC }\end{array}$ & $\begin{array}{c}\% \\
\text { Clay }\end{array}$ & $\begin{array}{c}\% \\
\text { Silt }\end{array}$ & $\begin{array}{c}\% \\
\text { Sand }\end{array}$ & $\begin{array}{l}\% \\
\mathrm{~N}\end{array}$ & $\begin{array}{c}\mathrm{pH} \\
\mathrm{H}_{2} \mathrm{O}\end{array}$ & $\mathrm{H}^{+}$ & $\begin{array}{c}\% \\
\text { O.C. }\end{array}$ & $\begin{array}{c}P \\
\mu g / g\end{array}$ & $\begin{array}{c}\mathrm{K}^{+} \\
\mathrm{cmol} / \mathrm{kg}\end{array}$ & $\begin{array}{c}\mathrm{Na}^{+} \\
\mathrm{cmol} / \mathrm{kg}\end{array}$ & $\begin{array}{c}\mathrm{Ca}^{2+} \\
\mathrm{cmol} / \mathrm{kg}\end{array}$ & $\begin{array}{c}\mathrm{Mg}^{2+} \\
\mathrm{cmol} / \mathrm{kg}\end{array}$ & $\begin{array}{c}\mathrm{CEC} \\
\mathrm{cmol} / \mathrm{kg}\end{array}$ & $\% \mathrm{BS}$ \\
\hline $0-15$ & 1.09 & 62.1 & 48.4 & 17.4 & 4.0 & 78.6 & 0.03 & 6.07 & 0.16 & 3.92 & 1.28 & 0.71 & 0.87 & 2.34 & 2.11 & 6.03 & 97.42 \\
\hline $15-30$ & 1.21 & 58.5 & 44.6 & 21.4 & 10.0 & 68.6 & 0.02 & 5.89 & 0.10 & 2.57 & 0.97 & 0.70 & 0.72 & 1.84 & 1.67 & 4.93 & 98.01 \\
\hline
\end{tabular}

Table 5. Physical and chemical properties of the surface samples of the studied site under traditional tillage.

\begin{tabular}{|c|c|c|c|c|c|c|c|c|c|c|c|c|c|c|c|c|c|}
\hline $\begin{array}{l}\text { Depth } \\
\text { cm }\end{array}$ & $\begin{array}{c}\text { Bulk } \\
\text { Density } \\
\mathrm{g} / \mathrm{cm}^{3}\end{array}$ & $\begin{array}{c}\text { Porosity } \\
\%\end{array}$ & $\begin{array}{c}\% \\
\text { WHC }\end{array}$ & $\begin{array}{c}\% \\
\text { Clay }\end{array}$ & $\begin{array}{c}\% \\
\text { Silt }\end{array}$ & $\begin{array}{c}\% \\
\text { Sand }\end{array}$ & $\begin{array}{l}\% \\
\mathrm{~N}\end{array}$ & $\begin{array}{c}\mathrm{pH} \\
\mathrm{H}_{2} \mathrm{O}\end{array}$ & $\mathrm{H}^{+}$ & $\begin{array}{c}\% \\
\text { O.C. }\end{array}$ & $\begin{array}{c}\mathrm{P} \\
\mu \mathrm{g} / \mathrm{g}\end{array}$ & $\begin{array}{c}\mathrm{K} \\
\mathrm{cmol} / \mathrm{kg}\end{array}$ & $\begin{array}{c}\mathrm{Na} \\
\mathrm{cmol} / \mathrm{kg}\end{array}$ & $\begin{array}{c}\mathrm{Ca}^{2+} \\
\mathrm{cmol} / \mathrm{kg}\end{array}$ & $\begin{array}{c}\mathrm{Mg}^{2+} \\
\mathrm{cmol} / \mathrm{kg}\end{array}$ & $\begin{array}{c}\mathrm{CEC} \\
\mathrm{cmol} / \mathrm{kg}\end{array}$ & $\%$ BS \\
\hline $0-15$ & 1.02 & 56.20 & 51.7 & 14.4 & 6.0 & 79.6 & 0.02 & 5.92 & 0.11 & 3.14 & 0.97 & 0.68 & 0.74 & 1.93 & 1.63 & 4.98 & 97.84 \\
\hline $15-30$ & 1.07 & 59.10 & 47.8 & 19.4 & 8.0 & 72.6 & 0.01 & 4.87 & 0.07 & 2.35 & 0.68 & 0.51 & 0.70 & 1.77 & 1.70 & 4.68 & 98.53 \\
\hline
\end{tabular}

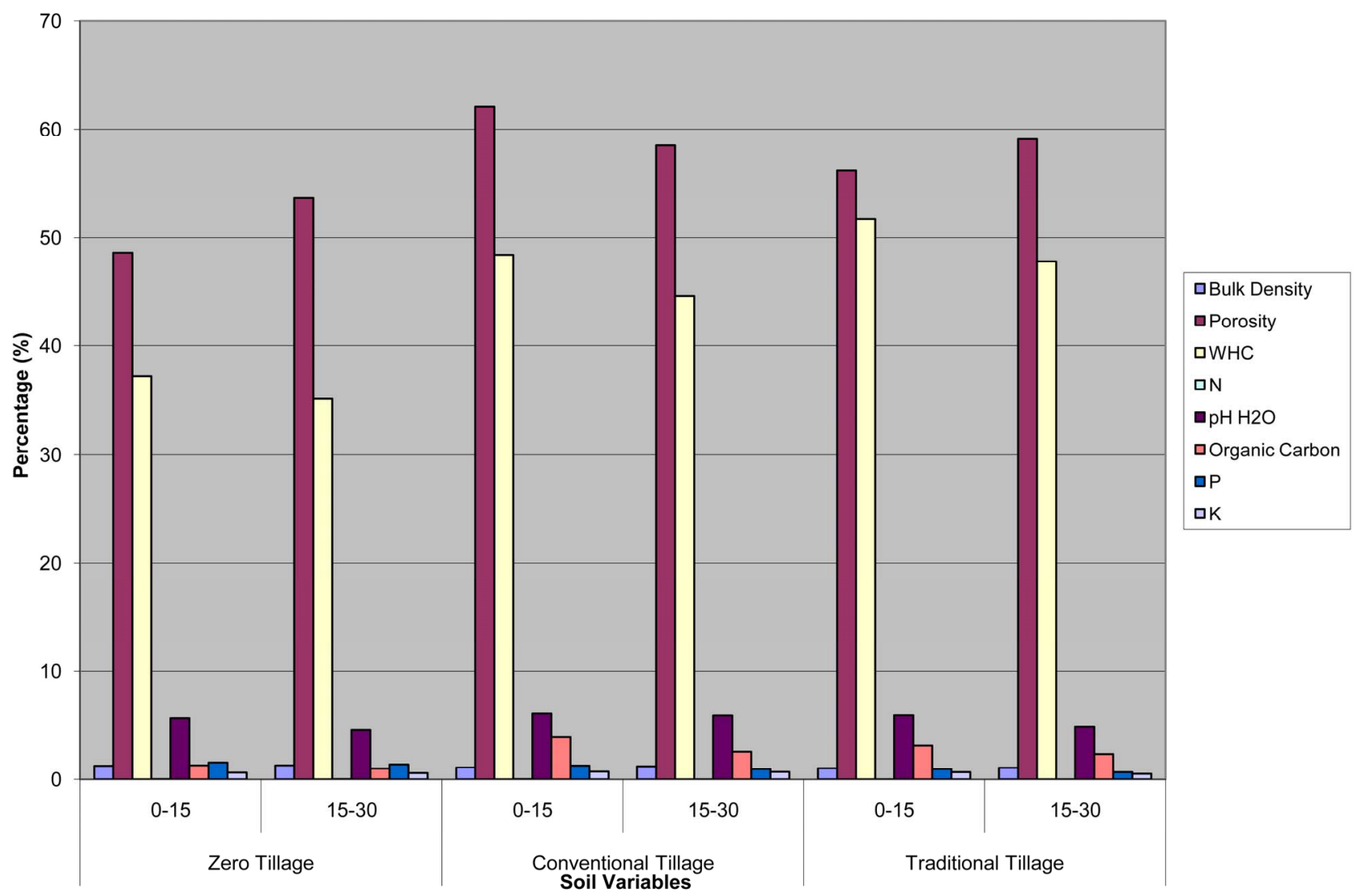

Figure 1. Soil properties under the three tillage systems at $0-15 \mathrm{~cm}$ and $15-30 \mathrm{~cm}$ depths $\mathbf{P}>0.05$. 


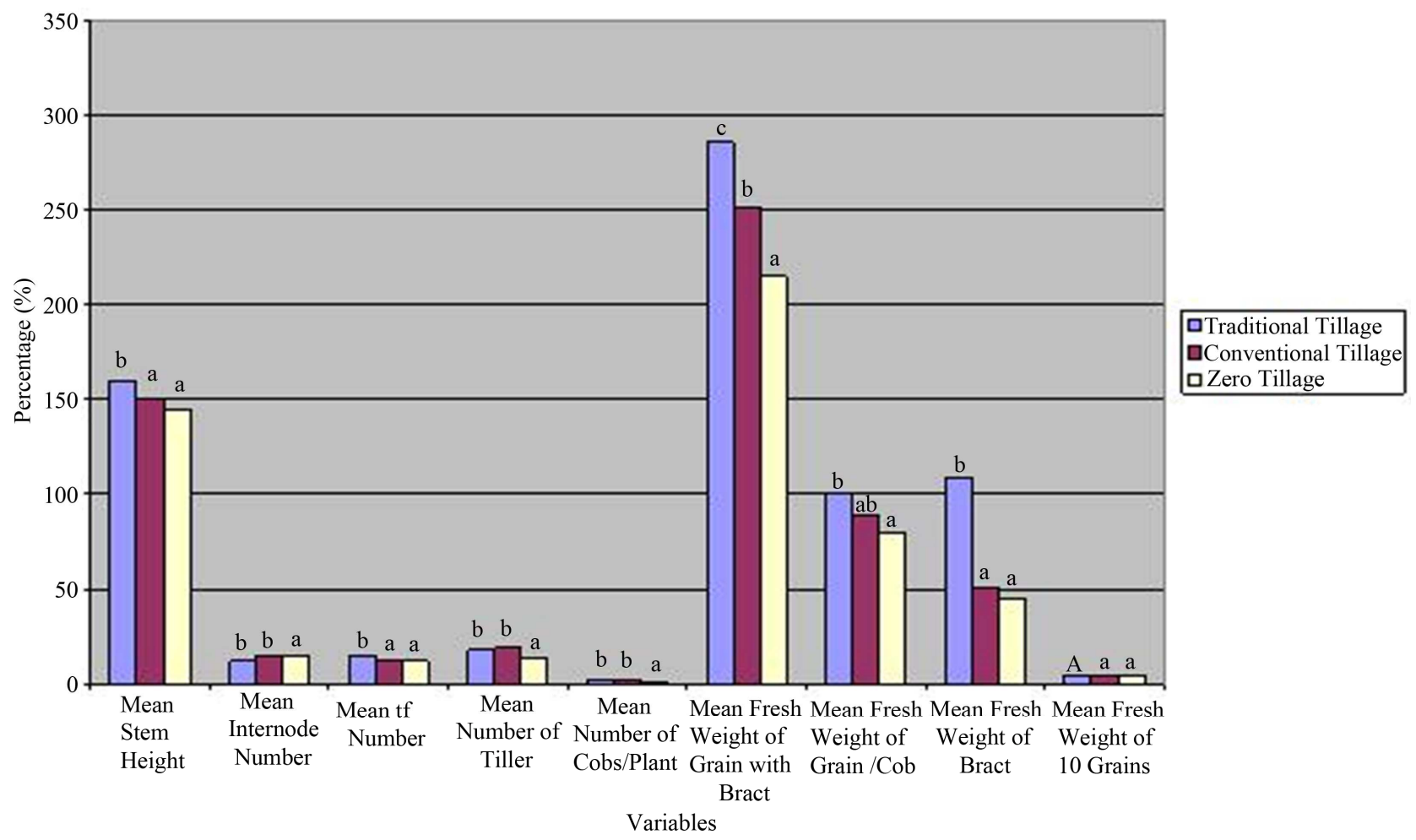

Figure 2. The agronomic variables of planted crop under the three tillage systems at $0-15 \mathrm{~cm}$ and $15-30 \mathrm{~cm}$ depths $P>0.05$. Note: Variables with the same letters are not significantly different from each other.

concentrating plant nutrients for better plant growth and development. Changes in chemical properties are dependent mainly on the organic matter content of the soil which was observed to be low in the studied soil under traditional tillage system. This must have been due to the soil manipulation, which optimized condition for seed germination and seedling emergence. Traditional tillage system generally improves soil drainage and crop performance compared with that planting on heavy soils and sandy loam soil [16]. (Similar results were also reported by [17]. From the aforementioned yield and yield components of maize, traditional tillage performed better compared with conventional and zero tillage systems. Unger [8], Singh and Rachiee [18], and Nitant and Singh [19], reported that deeper ploughing prior to ridging allows maximum absorption of rainwater and reduces weed population at the initial stage of crop growth which ultimately increases crop yield attributes. Ajuwon [20], observed that in relatively low rainfall areas in Nigeria, zero tillage system was found to produce lower yields of maize on topsoil with penetration resistance of greater than 0.05 MPA or with minimal earthworm activity.

The three tillage systems showed significant difference in the morphological properties of maize except in fresh weight of 10 grains at $\mathrm{p}<0.05$.

Furthermore, traditional tillage is better than zero tillage. In terms of cost of herbicides, conventional tillage is better than zero tillage. This possibly was due to poor permeability [15], poor aeration and compaction of the zero tillage.

The poor growth in zero tillage could also be a result of reduced infiltration rate according to. However, with high soil temperature it can be shown that zero tillage has potential for all year round maize production especially when the rainfall regime is not high. According to [21], the higher the soil moisture under zero tillage is, the lower the rate of maize production is in the wet season. It was noted that weed development was more pronounced on zero tillage.

\section{Summary and Conclusion}

Inappropriate tillage systems have been identified as major constraints to major staple crop especially maize production in the savannah agro-ecological zones in South Western Nigeria. The traditional tillage system provides a more favorable soil environment for crop growth and yield than those which are planted using conventional and zero tillage systems.

The difference in yield was as a result of the lower bulk density which gave room for the pulverization of the soil causing increased plant root proliferation and optimal utilization of soil nutrients. Zero tillage system in the savannah vegetation will require an effective system of weed control. For the land to be effectively utilized under these three tillage system, the use of fertilizers is neces- 
sary due to the low nutrients observed in the soils. Statistically, significant differences among the three tillage systems were more pronounced in the traditional tillage except in fresh weight of ten grains. Based on the observed results, the traditional tillage should be given the highest priority for maize production in the savannah vegetation for optimum performance, proper soil management and economic benefits.

Traditional tillage (the ridge method) has been found to be an effective soil conservation practice, which can reduce soil degradation in the study area considering the soil types.

\section{REFERENCES}

[1] J. H. Davies, "Tillage Research and Development in Nigeria," Proceedings of the First National Tillage Symposium of the NSAE, 1983, pp. 15-20.

[2] G. A. Makanjuola, "Appropriate Machines for Tillage in Nigeria,” Proceedings of the First National Tillage Symposium of the NSAE, 1983, pp. 21-34.

[3] T. I. Ashaye, "Suitability of Nigerian Soils to Mechanical Cultivation," Proceedings of the First National Tillage Symposium of the NSAE, 1983, pp. 57-69.

[4] R. Lal, "Importance of Tillage System in Soil and Water Management in the Tropics, in Soil Tillage and Crop Production,” In: R. Lal, Ed., IITA Proc. Series, No. 2, 1979, pp. 25-32.

[5] R. Lal, "Soil Tillage and Crop Production,” IITA, Ibadan, 1979.

[6] R. Lal, "Mechanized Tillage System, Effects on Properties of a Tropical Alfisoil in the Watershed Cropped to Maize,” Soil Tillage Research, Vol. 6, 1985, pp. 149-162.

[7] N. R. Hulugalle, R. Lal and O. A. Opara-Nadi, "Effect of Spatial Orientation of Mulch on Soil Properties and Growth of Yam (Dioscorea rotundata) and Cocoyam (Xanthosoma sagitifolium) on an Ultisol,” J. Root Crops, Vol. 12, 1986, pp. 37-45.

[8] P. Unger, "Conservation Tillage Systems," Advances in Soil Sciences, Vol. 13, 1990, pp. 27-68.
[9] R. Lal, "Effect of Slope Length on Erosion of an Alfisol in Western Nigeria," Geoderma, Vol. 31, No. 3, 1983, pp. 185-193. doi:10.1016/0016-7061(83)90012-5

[10] G. H. Bouyoucous, "A Recalibration of the Hydrometer Method for Making Mechanical Analysis,” Agronomy Journal, Vol. 43, No. 9, 1951, pp. 434-438. doi:10.2134/agronj1951.00021962004300090005x

[11] E. O. Mclean, “Aluminium: In Methods of Soil Analysis,” In: C. A. Black, Ed., 1965.

[12] M. L. Jackson, “Soil Chemical Analysis,” Prentice Hall, New York, Agronomy No. 9, Part 2, American Society of Agronomy, Madison, 1962, pp. 978-998.

[13] R. H. Bray and I. T. Kurtz, "Determination of Total Organic and Available Forms of Phosphorus in Soils," Soil Science, Vol. 59, No. 1, 1945, pp. 39-46.

[14] A. Walkley and C. A. Black, "Determination of Organic Matter in the Soil Science,” Vol. 37, 1934, pp. 540-556.

[15] G. Osuji, "Zero-Tillage for Erosion Control and Maize Production in the Humid Tropics," Journal of Environmental Management, Vol. 23, 1990, pp. 193-201.

[16] J. O. Akinyemi, O. E. Akinpelu and A. O. Olaleye, "Performance of Cowpea under Three Tillage Systems, on an Oxic Pareustaff in South Western Nigeria,” 2003.

[17] D. Nangju, "Effect of Density, Plant Type and Season on Growth and Yield of Cowpea," Journal of the American Society for Horticultural Science, Vol. 104, No. 4, 1979, pp. 466-470.

[18] Singh and Rachiee, International Symposium on Pests of Grain Legumes, Ibadan, 8-13 November 1976.

[19] H. S. Nitant and P. Singh, "Effect of Deep Tillage on Dry Land Production of Red Grain (Cajanus cajan L.) in Central India,” Soil and Tillage Research, Vol. 34, No. 1, 1995, pp. 17-26. doi:10.1016/0167-1987(94)00454-M

[20] S. O. Ajuwon, "Intrinsic Deficiencies of Zero Tillage," Proceedings of the 1st National Tillage Symposium, Ilorin, 22-25 November 1983, 25 p.

[21] W. L. Lindsay, P. L. G. Vlek and S. H. Chien, "Phosphate Minerals,” In: J. B. Dixon and S. B. Weed, Eds., Minerals in Soil Environment, 2nd Edition, Soil Science Society of America, Madison, 1989, pp. 1089-1130. 